\title{
The role of engineer in cost management Ellen Lau
}

\section{Introduction}

The role of engineer in civil engineering projects has changed from times to times throughout the years. ${ }^{1}$ Recent studies (e.g. Hansen, Lee, $\left.{ }^{1,2}\right)$ consider that engineers are all-round professionals who can apply special skills and knowledge to make civil engineering works into practice, including advising clients on selection of suitable designs, materials and construction methods and in charge of master program to collaborate work with other professionals. Although the duties of engineers may vary project from project due to the project specific nature, several standard forms of contract (including the Institution of Civil Engineers' Conditions of Contract (7th Edition, UK) and the General Conditions of Contract for Civil Engineering Works ${ }^{3}$ point out that the Engineer is also responsible for drawing up the construction contract of the project, impartially interpret contract documents and administers the terms of that contract formed between the employer and the contractor. Engineer involvement in cost management aspect in civil engineering project includes preparation of subsidiary estimates and budget estimates, issuing detailed drawings and design, approving materials and workmanship, measuring up and issuing certificates, issuing extra-works orders and variation orders. ${ }^{1}$ However, there is no detail for describing how project cost management is carried out and engineers may require additional training in doing the job comprehensively.

\section{Cost management}

According to $\mathrm{PMI},{ }^{4}$ cost management literally means cost planning and cost control while cost planning is carried out at the pre-contract stage and cost control at the post contract stage or the construction stage. Cost planning refers to three processes, namely cost estimating, cost budgeting and cost check. In building contracts, quantity surveyors generally involve in contract management and cost management. This includes pricing and preparing the tender documents, and provision of post-contract administration service, while risk analysis is conducted to determine the risks attaching to the bonds, warranties, insurances and guarantees covered by the contract. ${ }^{5}$ In the post-contract stage, quantity surveyor's consultancy service is provided in contract management with respect to the assessment of variation orders and contractual claims, and the preparation of the final account. It is noted that these contractual duties are related to the cost aspects arising from the contractual issues. From a quantity surveying perspective, the cost management functions in civil engineering project can be viewed at the two stages mentioned above. At the pre-contract stage (pre-tendering and post-tendering), a preliminary estimate or forecast is established with the provision of the feasibility study / conceptual design which may later lead to the preparation of the tender document. At the post-contract stage, the cost management function is mainly vested in cost control. Since contingency reserve is usually allowed in the tender/contract for unforeseeable events or variation orders based on the monetary representation of the likely risks, close monitoring of the liquidated capital is also a demanding job.

According to a research carried out by the author Lau, ${ }^{6}$ the three factors considered highly influencing project costs are: contract management factor, economic and financial factor and, project issue factor. The contract management factor contains items that
Volume 3 Issue 3 - 2017

\author{
Ellen Lau \\ City University of Hong Kong (former), China
}

Correspondence: Ellen Lau, City University of Hong Kong (former), HKSAR, China, Email bsellenl@outlook.com

Received: June 24, 2017 | Published: September 01, 2017

are considered to be related to the administration of the clause that stated in the construction contract. The elements include valuation of variation, assessment of claims, re-measurement of the provisional quantities etc. The economic and financial factor comprises items that are difficult to control by the construction parties but can have a huge impact on the project costs. Examples of the items in the economic and financial factor include inflation rate and exchange rate. The project issue factor contains items that are related to a particular project such as the contract type, program and site conditions of the project.

Two significant findings are noted in this research study Lau. ${ }^{6}$

1. The "market conditions", "inflation rate" and "claim assessment" are high cost impact items in civil engineering projects;

2. Project delay, project design and costing issues are the risks that frequently exist and have cost impact in civil engineering projects.

This finding echoes a recent study by Olawale and $\operatorname{Sun}^{7}$ which has suggested that project delay and design changes are important factors inhabiting the ability of industrial practitioners in controlling the project cost. It is considered that the usual tight schedule allowable for project development has often made the design immature before tender invitation. This in turn results in numerous variation orders at the post-contract stage. Moreover, disputes may arise about the variation order if the change is a design change or a design development of which time and cost compensation is not provided.?

To summarize the results of the study, it is found that "external factors" and "contractor capability" have significant influence on the cost management aspects in civil engineering projects. It is also found that the effect of "project issue factor" on project cost is significantly influenced by the cost management aspects Thus it is considered that attention should be paid to the cost management aspects and cost risks so as to sustain better cost control in civil engineering projects. To conclude, there should be an independent consultant monitoring the cost management aspects of civil engineering projects or to have engineers trained with quantity surveying skills together with financial and economic knowledge as to embrace the multi-faceted cost impacts on civil engineering projects. ${ }^{8,9}$

\section{Acknowledgments}

None. 


\section{Conflicts of interest}

The authors declare that they have no conflicts of interest.

\section{Funding}

None.

\section{References}

1. Lee YS. Role of the Engineer under the Framework of General Conditions of Contract for Civil Engineering Works in Hong Kong, MA (Arbitration and Dispute Resolution), City University of Hong Kong, China. 2003.

2. Hansen Z. Civil Engineer's Handbook of Professional Practice. ASCE Press, Wiley Publisher; 2011.

3. HKSAR. Government General Conditions of Contract for Civil Engineering Works, Government of Hong Kong Special Administration Region, China. 1999.
4. PMI. Project Management Body of Knowledge. 3rd ed. PMI, UK; 2004.

5. RICS. Cost management in engineering construction projects: guidance notes, London: Royal Institute of Chartered Surveyors, China. 1992.

6. Lau HLE. An Investigation of the Role of QS in Infrastructure Projects. Research report, Hong Kong Institute of Surveyors, China. 2013.

7. Olawale YA, Sun M. Cost and time control of construction projects: inhibiting factors and mitigating measures in practice. Construction Management and Economics. 2010;28(5):509-526.

8. Eggleston B. The ICE conditions of contract. 7th edn. Oxford, Malden, MA: Blackwell Science, UK; 2001.

9. Nima MA, Abdul Kadir NR, Jaafar MS. Evaluation of the engineer's personnel's role in enhancing the project constructability. Facilities. 1999;17(11):423-430. 